Article

\title{
Do Rural Policies Impact on Tourism Development in Italy? A Case Study of Agritourism
}

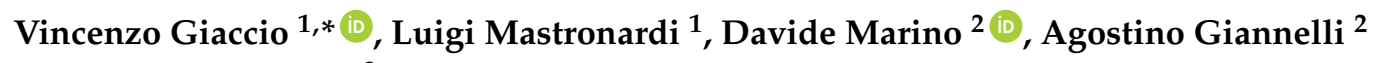 \\ and Alfonso Scardera ${ }^{3}$ \\ 1 Department of Economics, University of Molise, Via De Sanctis, 86100 Campobasso, Italy; \\ luigi.mastronardi@unimol.it \\ 2 Department of Biosciences and Territory, University of Molise, C.da Fonte Lappone 8, 86090 Pesche (IS), \\ Italy; dmarino@unimol.it (D.M.); giannelliagostino3@gmail.com (A.G.) \\ 3 Council for Agricultural Research and Economics, Via Gianbattista Vico, 4, 86100 Campobasso, Italy; \\ alfonso.scardera@crea.gov.it \\ * Correspondence: giaccio@unimol.it; Tel.: +39-0874-404404
}

Received: 17 July 2018; Accepted: 13 August 2018; Published: 18 August 2018

\begin{abstract}
This paper investigates how and to what extent European and national policies have financed Italian agritourism. It analyses financial support derived from the Common Agricultural Policy (CAP) (First and Second Pillar) and national and local subsidies. For this purpose, the authors have proposed a comparative analysis between Italian agritourism and farms without tourism activities, by stressing the distribution of public financial supports concerning the 2007-2013 programming period of the European Union (EU) for Rural Development. The empirical analysis is based on the Italian Farm Accountancy Data Network (FADN) dataset. The data were stratified by altimetry zone and farm size. Descriptive statistics and the Analysis of Variance (ANOVA) for each group were used. The main results show how the Second Pillar has mainly supported small and medium-sized farms with tourism activities and located in disadvantaged areas. This study could be useful to policymakers regarding the evaluation of the mission for diversification in agriculture, represented here by the carrying out of tourist activities on farms and the contribution for the retention of small-scale farms in marginal areas.
\end{abstract}

Keywords: diversification; CAP; RDP; subsidies; FADN

\section{Introduction}

This paper analyses the relationship between rural policies and agritourism development in Italy.

The starting hypothesis is that the Italian farms have different behaviours in access to financial resources for rural development in relation to the presence or absence of tourism activities on the farm.

Rural tourism is considered by the literature as a complex and vastly differentiated phenomenon [1] whose economic, social, and environmental effects for populations and territories depend on the relationships between public and private actors who define the connections between tourism products and local resources [2].

Farms are certainly among the main actors in this phenomenon and the tourism activities carried out on-farm represent a subset of rural tourism [3] based on the use of resources present in the territory $[4,5]$.

The implementation of tourism activities on-farm is a form of diversification of agricultural activities, a process that has consistently accompanied European farming in recent decades and was born out of necessity - especially in the case of small and medium-sized farms-to find ways to increase income from agricultural activities, and in recognition of the role that agriculture places on 
the relationship between communities' natural resources and rural areas [6,7]. This process, strongly supported by agricultural and rural development policies and implemented in the Agenda 2000, has significantly influenced the aims of instruments for financing these policies, identified as the First and Second Pillars of the Common Agricultural Policy (CAP).

This has consequently led to a reshaping of traditional agricultural activities that continue to represent the main activities in economic and social terms, especially in the most marginal areas. Traditional agriculture is no longer the exclusive activity, however [8]. Non-agricultural activities, including tourism, are becoming increasingly important for development purposes.

Diversification in agritourism is manifested through the presence of recreational-cultural services (e.g., hospitality, dining), and through the preservation and enhancement of the territory (e.g., direct selling, birdwatching) [9].

Agritourism is considered a key factor for local development [10-12] (Muresan et al., 2016), in particular for marginal rural areas where the possibilities to develop alternative job options are restricted [13] or where the environmental and cultural heritage are strongly appreciated by tourists [14].

There is wide and consolidated literature on the economic and social benefits of agritourism activities $[15,16]$. As far as environmental benefits, empirical analyses, mostly case studies, show positive performances related to tourism farms, such as soil conservation, ecosystem services conservation with the main attention to landscapes and biodiversity $[17,18]$. Agritourism often generates a different mosaic of landscapes, thanks to a lower presence of monoculture productions. The attention of the farmer to environmental aspects and care of the territory is also a consequence of tourist demand for a greater variety of products [19] and traditional agricultural landscapes [20-22].

In Italy, agritourism is considered a favourite way to diversify farm activities. Agritourism is a well-established phenomenon in Italy and likely represents the most radical innovation in Italian agriculture [23]. Agritourism constitutes an Italian speciality in view of rural tourism at the European level. This is due to the particular national law that governs this phenomenon.

Briefly, in Italy, agritourism can only be performed by the farmer and his family members (Law n. 96/2006). Moreover, 'the agricultural activity of the farm and not its tourism activities, must be predominant' [24]. This predominance of agricultural activity is fixed in terms of working hours and not in terms of income. In other words, it 'forces' the agritourism entrepreneur to dedicate himself mainly to agricultural practices.

The rationale of Italian legislation is fourfold, pursuing ambitious goals related to: (i) economic issues, by integrating farmers' revenues and by promoting local products; (ii) socio-cultural issues, by consolidating the relations between the city and the countryside, and by preserving local traditions; (iii) environmental issues, by protecting the environment and the landscape, and (iv) occupational issues, by creating new job opportunities, especially in marginal areas, with the aim of limiting the exodus in particular of a young and female labour force.

These goals emphasise the economic, social and environmental role of Italian agritourism. At the same time, they tend to justify the subsidies that the institutions pour into the diversification of agricultural activities, such as agritourism [25].

The literature is unanimous in considering the choice to diversify activities on the farm very sensitive to funding allocated by the European Union (EU) [26]. Nonetheless, the literature still lacks detail on the impact of these subsidies and incentives on farm diversification.

In this context, the idea is to analyse and evaluate the influence of policies and financial supports on Italian agritourism, in the year 2015, related to the EU programming period 2007-2013.

Support for Rural Development is the 2nd Pillar of the CAP. The national rural development programme (NRDP) 2007-2013, has allocated a budget of $€ 16,687$ million ( $€ 8292$ million from the EU budget, $€ 6908$ million of national funding, and $€ 1487$ from Regions and Provinces). Four themes (Axis) and 40 Measures have been foreseen. In total, 38.8\% of the available public resources have been dedicated to Axis 1 ("Improving the competitiveness of the agricultural and forestry sector", 
14 Measures); to Axis 2, 42\% ("improving the environment and the countryside", 13 Measures); to Axis $3,8.5 \%$ ("improving the quality of life in rural areas and encouraging diversification of the rural economy", 8 Measures) and to Axis 4, 8.1\% ("Leader Programme", 5 Measures). Briefly, in the total of Regional Development Programmes (RDP), the Measure "Agri-environment payments" has taken almost a quarter of the entire financial allocation (22.3\%), while for the Measure "Modernization of the Farms," $14.2 \%$ of public resources have been reserved. Among the themes related to the promotion of the diversification of activities on farms (Axis 4), the measure "diversification into non-agricultural activities," has been the most quoted measure by the Italian Region (3.5\% of the financial resources) [27]. For this purpose, we propose a comparison between Italian farms with agritourism and farms without agritourism, in relation to public funding received.

The empirical analysis is based on the Italian Farm Accountancy Data Network (FADN) dataset. The data were stratified by altimetry zone and farm size. We used descriptive statistics and performed an Analysis of Variance (ANOVA) for each group, followed by a pairwise comparison between groups.

\section{Materials and Methods}

The data concerning Italian agritourism produced by the Italian National Institute of Statistics (ISTAT), are not adequate for an effective structural, economic and social analysis of the agritourism phenomenon. For this reason, here, the empirical analysis is based on the Italian FADN dataset. The European FADN was created to represent farms' technical and economic operation in the EU and on which it drafts agricultural and rural policies. The Italian FADN dataset represents the national agriculture in a statistically reliable way if we consider the farm's production system and economic size. In $2015,75 \%$ of the sample concerned specialised farming in arable crops, forest plantation, and cattle breeding.

As regards economic size, median classes are more representative and are especially considered, while it is not the same for the extreme classes of the sample.

Instead, the sample has a farm's distribution for altimetric zone comparable to the ISTAT Census, with a little predominance in hill areas, where $45 \%$ of the farms (against the $52 \%$ ) are considered.

Moreover, the Italian FADN sample highlights a greater number of male and young conductors (77\% and $12 \%)$ than the ISTAT Census (69\% and 10\%).

In both cases, the reason for these differences is probably to be found in the aforementioned more professional nature of FADN's farms.

The FADN dataset involves 11,009 observations, 401 corresponding to agritourism farms ( $3.24 \%$ of the sample).

Finally, and with regard to other characteristics of Italian agritourism, their distribution closely reflects the data collected by ISTAT.

For example, almost two-thirds of agritourism enterprises listed are distributed in internal areas, equally subdivided between hilly and mountainous areas and well over $80 \%$ of them are in Central and Northern Italy. In relation to business size, agritourism activities involve mostly small and medium farms; for them, agritourism plays an important role in the integration and diversification of income.

The FADN dataset contains information on all public funding given to farms. It classified the following typologies: (a) EU funds for production (First Pillar); (b) EU funds for rural development (Second Pillar), and (c) national funding (including regional and local ones).

The groups of farms with and without agritourism included in the FADN dataset have been compared using statistical tests on the differences between mean, median, and variance values of samples assuming a $p$-value equal to 0.05 as a threshold of acceptance. The tests adopted are of parametric type (Student's $t$-test and Fisher-Snedecor $F$-test) for mean and variance and non-parametric (Wilcoxon signed-rank $z$ test) for the median.

Successively, for each category of subsidy, the mean and median values were calculated for the altimetric zone and farm size (Standard Output) in the two groups. Then, the ANOVA was performed to evaluate if there were at least two groups whose means were significantly different. 
In this case, we proceeded to estimate the differences between all possible combinations of groups. Because of the consistent deviation between mean and median values (in this case the data were characterised by high variability), we preferred to proceed to the comparison between medians in place of their respective means using a non-parametric Mann-Whitney U-test with Bonferroni correction for multiple comparisons.

The null hypothesis underlying the test is that the samples come from populations with the same median. Therefore, any equality between the medians of the samples does not necessarily imply acceptance of the null hypothesis.

\section{Results and Discussion}

As shown in Table 1, significant differences may be observed in the mean and median values between farms with and without agritourism, concerning the Rural Development Programme (RDP) funding and non-EU funding (national and regional). In both cases, farms with agritourism receive a higher amount in comparison to other farms. This confirms that incentives may influence the tendency towards diversification [28].

Table 1. Descriptive statistics and tests on farms with and without agritourism. The amount of subsidies are expressed in Euros. The differences, if significant, are displayed with an asterix following the classification standard ${ }^{1}$.

\begin{tabular}{|c|c|c|c|c|c|c|c|c|c|}
\hline & \multicolumn{3}{|c|}{ Farms with Agritourism } & \multicolumn{3}{|c|}{ Farms without Agritourism } & \multicolumn{3}{|c|}{$t, z, F$ Test $^{2}$} \\
\hline & $\begin{array}{l}\text { First } \\
\text { Pillar }\end{array}$ & $\begin{array}{l}\text { Second } \\
\text { Pillar }\end{array}$ & $\begin{array}{l}\text { Non-EU } \\
\text { Funds }\end{array}$ & $\begin{array}{l}\text { First } \\
\text { Pillar }\end{array}$ & $\begin{array}{l}\text { Second } \\
\text { Pillar }\end{array}$ & $\begin{array}{l}\text { Non-EU } \\
\text { Funds }\end{array}$ & First Pillar & $\begin{array}{c}\text { Second } \\
\text { Pillar }\end{array}$ & $\begin{array}{l}\text { Non-EU } \\
\text { Funds }\end{array}$ \\
\hline Mean & 11,967 & 7422 & 6135 & 14,470 & 3741 & 3270 & $\begin{array}{l}t=1.013 \\
p=0.156\end{array}$ & $\begin{array}{c}t=-5.094 \\
p<0.001(* * *)\end{array}$ & $\begin{array}{c}t=-5.364 \\
\left.p<0.001{ }^{* * *}\right)\end{array}$ \\
\hline Median & 3755 & 1500 & 1880 & 4761 & 0 & 0 & $\begin{array}{c}z \text { (Wilcox. })= \\
0.538 \\
p=0.295\end{array}$ & $\begin{array}{c}z \text { (Wilcox.) }= \\
-3.898 \\
p<0.001\left(^{* * *}\right)\end{array}$ & $\begin{array}{c}z \text { (Wilcox.) }= \\
\quad-5.199 \\
\left.p<0.001{ }^{* * *}\right)\end{array}$ \\
\hline Variance & $\begin{array}{c}6.741 \times \\
10^{8}\end{array}$ & $\begin{array}{c}3.257 \times \\
10^{8}\end{array}$ & $\begin{array}{c}1.700 \times \\
10^{8}\end{array}$ & $\begin{array}{c}2.126 \times \\
10^{9}\end{array}$ & $\begin{array}{c}1.707 \times \\
10^{8}\end{array}$ & $\begin{array}{c}8.424 \times \\
10^{8}\end{array}$ & $\begin{array}{c}F=3.153 \\
p<0.001\left(^{* * *}\right)\end{array}$ & $\begin{array}{c}F=1.908 \\
p<0.001\left(^{* * *}\right)\end{array}$ & $\begin{array}{c}F=2.018 \\
\left.p<0.001{ }^{* * *}\right)\end{array}$ \\
\hline $\begin{array}{l}\text { Coefficient } \\
\text { of variation }\end{array}$ & 2.167 & 2.432 & 2.126 & 3.186 & 3.491 & 2.807 & & & \\
\hline
\end{tabular}

${ }^{1}$ The standard output (SO) of an agricultural product is the average monetary value of the total agricultural output of the farm, produced in a given region and referring to an agricultural year. The SO is used to classify farms by type of farming and by economic size. ${ }^{2} 0.05>p>0.01 ;\left({ }^{* *}\right) 0.01>p>0.001 ;\left({ }^{* *}\right) p<0.001$.

However, the differences in payments tied to the First Pillar are not significantly different between the two groups of farms. Consequently, they should not influence the choice to diversify, even if in some cases these payments play an important role in supporting the incomes of farmers [27].

The role of the RDP, however, should be very important for agritourism development, which is considered as a means to increase the functions of farms. European rural policies have been persisting in this way [29], giving incentives not only in financial terms to farms that diversify [30]. Thanks to this external economic support, agritourism has increased in importance in Europe, and particularly in Italy, whereas agritourism is considered the most important alternative to rationalisation and growth strategies in the context of structural change in agriculture and adjustments of European agricultural policy [31].

National and regional assistance, like the RDP, play significant roles in the choice of farms to diversify. These policies include measures for the development of agritourism, such as (1) businesses in protected areas; (2) adoption of a certification scheme for environmental quality; (3) food processing; (4) social and cultural activities, and (5) building up of direct selling points. Food processing and direct selling are the most frequent diversification activities and keep farm resources linked to agricultural supply chains. There is a positive relationship between income and some typical tourism activities, such as food and leisure services, cultural and sports activities [32]. Drivers such as direct selling, 
family employment, and environmental certification could be strengthened by territorial policies aimed at enhancing natural resources and endogenous potential [33].

Table 2 reports the mean and median values in relation to different altimetric zones. The tests performed on median values confirm the results emerging at the national level (Appendix A).

Table 2. Farms with and without agritourism. Mean values (upper) and median values (lower, in italics) in Euros for the altimetric zone.

\begin{tabular}{ccccccc}
\hline & \multicolumn{3}{c}{ Farms with Agritourism } & \multicolumn{3}{c}{ Farms without Agritourism } \\
\cline { 2 - 7 } & First Pillar & Second Pillar & Non-EU Funds & First Pillar & Second Pillar & Non-EU Funds \\
\hline \multirow{2}{*}{ Plains } & 22,383 & 2613 & 2618 & 24,295 & 2321 & 1748 \\
& 5086 & 0 & 0 & 7535 & 0 & 0 \\
\hline \multirow{2}{*}{ Inner hill } & 11,569 & 8833 & 5521 & 11,079 & 4093 & 3268 \\
& 3490 & 1500 & 1500 & 4526 & 0 & 0 \\
\hline \multirow{2}{*}{ Inner mountain } & 8996 & 8044 & 8290 & 6104 & 5770 & 6119 \\
& 4137 & 2962 & 4313 & 3427 & 1635 & 2000 \\
\hline \multirow{2}{*}{ Seaside hill and mountain } & 11,362 & 5131 & 5199 & 10,527 & 3373 & 2782 \\
& 2635 & 1400 & 1400 & 3713 & 0 & 0 \\
\hline
\end{tabular}

In particular, regarding First Pillar funding, the data do not show significant variation between the two sub-samples within the same areas where farms are located. Consequently, the differences observed within the groups probably depend on the different farm numbers.

Regarding payments linked to the Second Pillar, the farms with agritourism receive higher subsidies than the others, with the exception of the farms located in the plains. Nonetheless, the differences observed in the inner mountain and seaside hill and mountain areas are barely significant. In any case, these results highlight the role of policies considering the location of the farms and emphasise links between diversification and territorial factors [34].

In the case of national and regional grants, the differences in the values are significant in all zones with the exception of the plains. In these areas, farms with agritourism have higher median values. It is helpful to remember that agritourism is located mostly in the inner areas where there are higher concentrations of protected areas and eno-gastronomic resources, which are factors influencing the attractiveness of the area and tourist flow. This probably justifies the higher amount of funding received by agritourism relative to this form of assistance.

Table 3 shows the mean and median values relative to the economic size of the farms. Differences between the median values are highly significant (Appendix B). With reference to payments under the First Pillar, there is a significant difference in median values between the small and small to mid-sized farms with and without agritourism. Farms without agritourism actually receive a larger amount, which contributes to overall income generation. In this sense, it may be hypothesised that non-diversified farms receive partial integration from this form of funding. Conversely, diversification probably contributes significantly to the growth of income of smaller farms and consequently reduces their dependence on First Pillar payments.

Concerning RDP, regional and national-level funding, it is evident that the situation is practically homogeneous. The median values show that farms with agritourism receive more support in each farm size class, with the sole exception of large farms. Tourism activities carried out by farms are universally known to provide additional economic support, especially for small family businesses [35], which share the need to diversify activities and increase their income. Everywhere, the blending of agriculture and tourism is considered a successful strategy to diversify farm income, expand marketing and farm brand awareness, and level out seasonal fluctuations [36]. 
Table 3. Farms with and without agritourism. Mean values (upper) and median values (lower, in italics) in Euros by SO.

\begin{tabular}{|c|c|c|c|c|c|c|}
\hline & \multicolumn{3}{|c|}{ Farms with Agritourism } & \multicolumn{3}{|c|}{ Farms without Agritourism } \\
\hline & First Pillar & Second Pillar & Non-EU Funds & First Pillar & Second Pillar & Non-EU Funds \\
\hline \multirow{2}{*}{ Small } & 2276 & 2782 & 2126 & 3295 & 1002 & 809 \\
\hline & 1470 & 1264 & 1415 & 2166 & 0 & 0 \\
\hline \multirow{2}{*}{ Small-medium } & 3784 & 5447 & 3685 & 5704 & 2191 & 1810 \\
\hline & 1858 & 1835 & 2035 & 3764 & 0 & 0 \\
\hline \multirow{2}{*}{ Medium } & 8401 & 4323 & 5399 & 9506 & 3615 & 3636 \\
\hline & 4462 & 1660 & 2699 & 5785 & 0 & 0 \\
\hline \multirow{2}{*}{ Medium-large } & 22,943 & 12,905 & 9207 & 22,528 & 6200 & 5705 \\
\hline & 12,207 & 4113 & 3166 & 11,163 & 0 & 0 \\
\hline \multirow{2}{*}{ Large } & 46,099 & 21,049 & 21,152 & 63,225 & 8807 & 5716 \\
\hline & 8959 & 0 & 0 & 19,492 & 0 & 0 \\
\hline
\end{tabular}

In summary, public funding plays an important role in supporting business diversification and additionally, is a determining factor in development of business ideas [37,38]. The desire for additional financial support, such as non-refundable grants, may be the initial reason to diversify activities on a farm and start agritourism activities [39]. It is nonetheless necessary that these policies are accompanied by regional and state-level initiatives aimed at maintenance and valourisation of agricultural activities in specific contexts.

Among RDP measures, agritourism has benefited mostly from policies related to the quality of life and diversification of agri-environmental payments, which shows how these farms react to rural policy incentives related to sustainability.

The environmental performance of agritourism can be seen to be the result of a farm diversification process aimed at the development of environment-based services [40]. Agritourism is associated with positive effects on some environmental components, such as landscape, water and energy resources, biodiversity, as well as reduced use of fertilisers and pesticides in productive processes, and improvements in the quality of foods [41]. In this manner, agritourism businesses represent an opportunity to reduce the negative external effects of agriculture on the environment [42], even though their performance, from an economic and social point of view, is probably inferior to other companies operating in rural areas [43].

Other economic variables are more favourable to increasing agritourism income, including direct sales of farm products and environmental variables such as forest areas and organic certification. These drivers are not strictly connected to tourism activities. If properly exploited through policy interventions, these activities may represent not only a business opportunity for agritourism income, but also a good mechanism to support the development of rural areas by promoting new farm-related activities, new professional profiles, and new forms of employment [44].

Surely, the policies of recent years have played a significant role in supporting farm incomes. Policies directly targeting agritourism are important, but they are only one side of the coin; the other is made by regional development policies, which are equally important. Regional policies focus on more effective exploitation of local resources, and provision of an appropriate infrastructure network and essential services to visitors in a specific region [45].

\section{Conclusions}

This study shows how Italian farms in the FADN dataset behave very differently in accessing different policies in relation to the presence or absence of agritourism activities. Higher levels of funding under the Second Pillar of the CAP, as well as state funding show, at the same time, that entrepreneurial decision in favour of agritourism activities are embedded within broader choices regarding diversification and multifunctionality.

To summarise, payments for the First Pillar have mostly benefited large, market-oriented farms, located in the plains [46]. In contrast, some measures of the Second Pillar, specifically those identified 
as compensatory payments and agri-environmental payments have generally benefited small and medium farms that are, from a territorial and economic perspective, located in marginal areas, where the concentration of Italian agritourism is higher.

This suggests a greater propensity of Italian agritourism towards sustainable choices from an environmental point of view.

Probably, the sustainable approach of Italian farms is a consequence of a national law on the matter that in fact forces the farmer to deal more with farming rather than tourism.

With regard to economic and social sustainability, some studies show how variables, such as accommodation, food service and leisure, cultural and sports activities, direct selling, forest cover, and environmental certifications are important drivers for agritourism revenue and family employees on farms $[47,48]$.

In other words, the impression is that tourism on the farm can become the economic activity of redemption for rural areas where the is a phenomenon of marginality, with positive implications for the natural resources of the territories involved [49].

This propensity is in line with the general objectives of the EU's rural policies over recent decades, such as the sustainable development of rural economic activities, including tourism and environmental protection [50].

Therefore, this suggests the need for greater attention in the future of European and national policymakers towards the financing of agritourism activities, as well as other forms of farm diversification.

Nevertheless, for the next long-term EU budget 2021-2027, the Commission has proposed to modernise and simplify the Common Agricultural Policy (CAP), providing for at least $30 \%$ of each rural development national allocation to be dedicated to environmental and climate measures. Forty percent of the CAP's overall budget is expected to contribute to climate action.

With regard to this research, for new CAP 2021-2027, the Commission estimates an average contraction of resources for the CAP of about 5\%, compared to 2014-2020, which will affect rural development more $(-10 \%)$ - whose resources can be safeguarded thanks to the increase in national co-financing - and less direct payments $(-4 \%)$. According to the Commission, the resources for Italy will be 24,921.3 million euro for direct payments $(-3.9 \%), 8892.2$ million euro for rural development $(-15.3 \%)$, and 2545. 5 million euro for other pre-allocated items (-2.5\%) (European Commission, 2018).

The cut could penalise farms that diversify, including agritourism and consequently Italian Government should make up the difference to support its own resource. Nevertheless, and in light of the data and analyses undertaken, it is still not a simple matter to determine whether agritourism activities are positively influenced by payments under the Second Pillar and by national and regional funding, or whether the business strategy of diversification also concerns, beyond productive activities, income from different subsidies. It is necessary, therefore, to go in depth further to investigate the importance of agritourism in the business as a whole. It would be reasonable to assume that on farms in which agritourism represents the core business, the policies are utilised mostly as sources of financing. Where, instead, agritourism is used to generate and integrate income, businesses can utilise finances of the Second Pillar as well as funding from the state to move towards more sustainable production of goods and services, and towards activities that integrate better with agritourism activities. In addition, the decision to diversify is not strictly dependent on the opportunities offered by community and national policy but is also influenced by appropriate value creation strategies [51,52].

Author Contributions: The research was designed and performed by V.G., L.M. and D.M. The data was collected by A.S. The formal analysis was performed by A.G. Finally, the paper was written by V.G. and L.M. All the authors read an approved the final manuscript.

Funding: This research received no external funding.

Conflicts of Interest: The authors declare no conflict of interest. 


\section{Appendix A}

ANOVA analysis on farms with and without agritourism for altimetric zones (SS = sum of squares; $\mathrm{df}=\mathrm{degrees}$ of freedom; MS = mean square). The diagonal matrix reports the corresponding values of $p$ and their degrees of significance. This matrix also contains a comparison between farms with and without agritourism relative to the same altimetric zone. $\mathrm{A}=$ plains; $\mathrm{B}=$ inner hill; $\mathrm{C}=$ inner mountain; $\mathrm{D}=$ seaside hill and mountain.

\begin{tabular}{|c|c|c|c|c|c|c|c|c|c|c|c|c|c|c|c|}
\hline \multirow{3}{*}{$\begin{array}{c}\text { Variance } \\
\text { between } \\
\text { groups }\end{array}$} & \multicolumn{5}{|c|}{ EU Funds } & \multicolumn{5}{|c|}{ Total RDP } & \multicolumn{5}{|c|}{ Non-EU Funds } \\
\hline & SS & $\mathrm{df}$ & MS & \multicolumn{2}{|c|}{ F } & sS & $\mathrm{df}$ & MS & \multicolumn{2}{|c|}{ F } & SS & df & MS & \multicolumn{2}{|c|}{ F } \\
\hline & $\begin{array}{c}4.71188 \times \\
10^{11}\end{array}$ & 7 & $\begin{array}{r}6.73125 \\
\times 10^{10}\end{array}$ & \multicolumn{2}{|c|}{33.32} & $\begin{array}{c}1.99732 \times \\
10^{10}\end{array}$ & 7 & $\begin{array}{c}2.85331 \\
\times 10^{9}\end{array}$ & \multicolumn{2}{|c|}{16.3} & $\begin{array}{c}2.56408 \times \\
10^{10}\end{array}$ & 7 & $\begin{array}{c}3.66297 \\
\times 10^{9}\end{array}$ & \multicolumn{2}{|c|}{43.05} \\
\hline $\begin{array}{l}\text { Variance } \\
\text { within } \\
\text { groups }\end{array}$ & $\begin{array}{c}1.84661 \times \\
10^{13}\end{array}$ & 9142 & $\begin{array}{c}2.01992 \\
\times 10^{9}\end{array}$ & \multicolumn{2}{|c|}{$p<0.001\left(^{* * *}\right)$} & $\begin{array}{c}1.60046 \times \\
10^{12}\end{array}$ & 9142 & $\begin{array}{c}1.75066 \\
\times 10^{8}\end{array}$ & \multicolumn{2}{|c|}{$p<0.001\left({ }^{* * *}\right)$} & $\begin{array}{c}7.77851 \times \\
10^{11}\end{array}$ & 9142 & $\begin{array}{c}8.50854 \\
\times 10^{7}\end{array}$ & \multicolumn{2}{|c|}{$p<0.001(* * *)$} \\
\hline \multirow[t]{3}{*}{ Total } & $\begin{array}{c}1.89373 \times \\
10^{13}\end{array}$ & 9149 & & & & $\begin{array}{c}1.62043 \times \\
10^{12}\end{array}$ & 9149 & & & & $\begin{array}{c}8.03491 \times \\
10^{11}\end{array}$ & 9149 & & & \\
\hline & \multirow{2}{*}{$\begin{array}{c}\text { Altimetric } \\
\text { zone }\end{array}$} & \multicolumn{4}{|c|}{ Farms without agritourism } & Altimetric & \multicolumn{4}{|c|}{ Farms without agritourism } & Altimetric & \multicolumn{4}{|c|}{ Farms without agritourism } \\
\hline & & A & B & $\mathrm{C}$ & D & zone & A & B & $\mathrm{C}$ & D & zone & A & B & $\mathrm{C}$ & D \\
\hline \multirow{4}{*}{$\begin{array}{c}\text { Farms } \\
\text { with } \\
\text { agritourism }\end{array}$} & $\mathbf{A}$ & 0.301 & 0.358 & 0.012 & 0.083 & $\mathbf{A}$ & 0.189 & 0.060 & $\begin{array}{c}<0.001 \\
(* * *)\end{array}$ & 0.374 & $\mathbf{A}$ & 0.065 & 0.105 & $\begin{array}{c}<0.001 \\
(* * *)\end{array}$ & 0.601 \\
\hline & B & $\begin{array}{c}<0.001 \\
(* * *)\end{array}$ & 0.079 & 0.249 & 0.820 & B & $\begin{array}{c}<0.001 \\
(* * *)\end{array}$ & $\begin{array}{c}<0.001 \\
(* * *)\end{array}$ & 0.892 & $\begin{array}{c}<0.001 \\
(* * *)\end{array}$ & B & $\begin{array}{c}<0.001 \\
(* * *)\end{array}$ & $\begin{array}{c}<0.001 \\
(* * *)\end{array}$ & 0.255 & $\begin{array}{c}<0.001 \\
(* *)\end{array}$ \\
\hline & $\mathrm{C}$ & $\begin{array}{c}<0.001 \\
(* * *)\end{array}$ & 0.241 & 0.079 & 0.663 & C & $\begin{array}{c}<0.001 \\
(* * *)\end{array}$ & $\begin{array}{c}<0.001 \\
(* * *)\end{array}$ & 0.055 & $\begin{array}{c}<0.001 \\
(* * *)\end{array}$ & $\mathrm{C}$ & $\begin{array}{c}<0.001 \\
(* * *)\end{array}$ & $\begin{array}{c}<0.001 \\
(* * *)\end{array}$ & $\begin{array}{c}0.003 \\
(* *)\end{array}$ & $\begin{array}{c}<0.001 \\
(* *)\end{array}$ \\
\hline & D & $\begin{array}{c}<0.001 \\
(* * *)\end{array}$ & 0.069 & 0.699 & 0.305 & D & $\begin{array}{c}<0.001 \\
(* * *)\end{array}$ & 0.117 & 0.479 & 0.010 & D & $\begin{array}{c}<0.001 \\
(* * *)\end{array}$ & 0.088 & 0.379 & $\begin{array}{c}0.005 \\
(* *)\end{array}$ \\
\hline
\end{tabular}

(i) $\left.0.05>p>0.01 ;(* *) 0.01>p>0.001 ;{ }^{* * *}\right) p<0.001$. 


\section{Appendix B}

ANOVA analysis on farms with and without agritourism by Business Standard Production class (SS = sum of squares; df = degrees of freedom; MS = mean squares). The diagonal matrix reports the corresponding values of $\mathrm{p}$ and their degrees of significance. The matrix also contains a comparison between farms with and without agritourism within the same altimetric zone. $1=$ small farms; $2=$ small to medium size farms; $3=$ medium size farms; $4=$ medium to large farms; 5 = large farms.

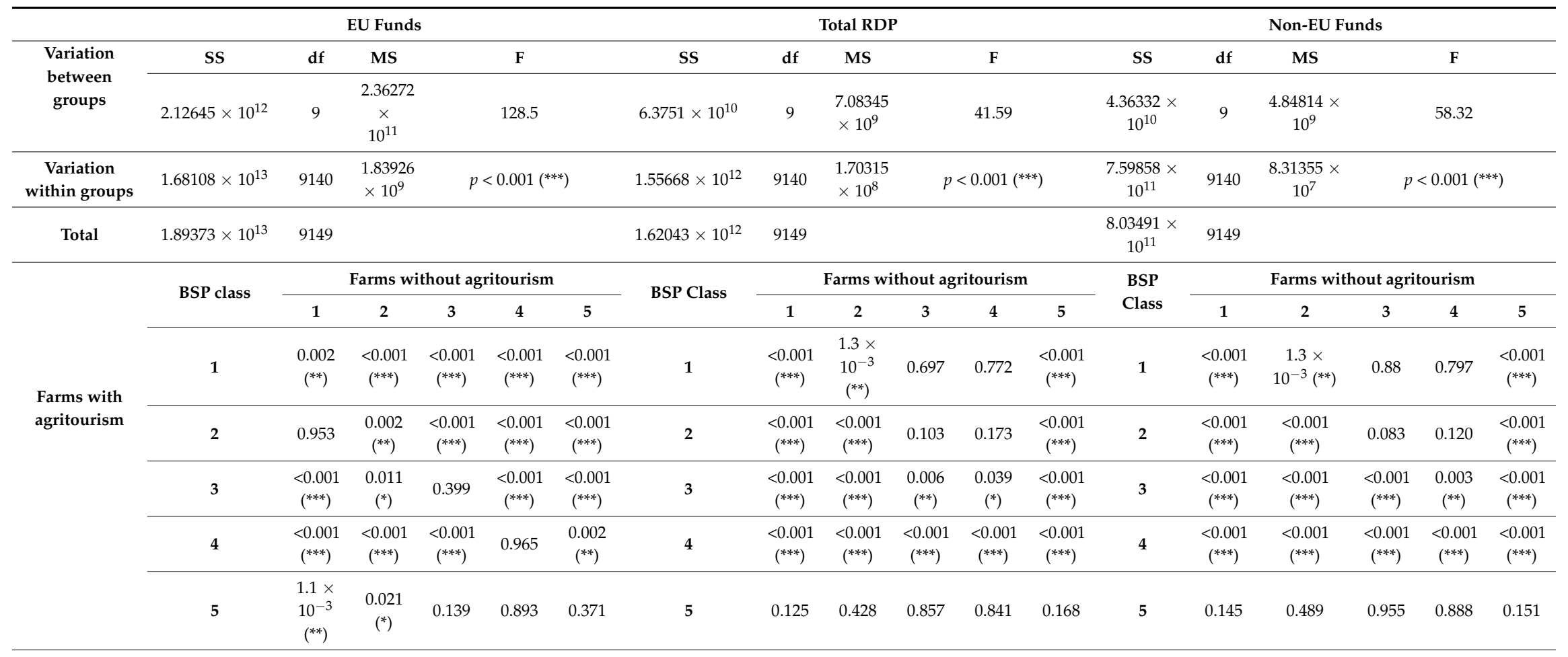

(ii) $\left.\left.0.05>p>0.01 ;{ }^{* *}\right) 0.01>p>0.001 ;{ }^{* * *}\right) p<0.001$. 


\section{References}

1. Frochot, I. A Benefit Segmentation of Tourists in Rural Areas: A Scottish Perspective. Tour. Manag. 2005, 26, 335-346. [CrossRef]

2. Pacciani, A. Aree Rurali e Configurazioni Turistiche; Pacciani, A., Ed.; Franco Angeli: Milano, Italy, 2011.

3. Phillip, S.; Hunter, C.; Blackstock, K. A Typology for Defining Agritourism. Tour. Manag. 2010, 31, 754-758. [CrossRef]

4. Hall, D.; Roberts, L.; Mitchell, M. New Directions in Rural Tourism; Hall, D., Roberts, L., Mitchell, M., Eds.; Ashgate: Aldershot, UK, 2003.

5. Cawley, M.; Gillmor, D.A. Integrated Rural Tourism: Concepts and Practice. Ann. Tour. Res. 2008, 35, $316-337$. [CrossRef]

6. Salvioni, C.; Ascione, E.; Henke, R. Structural and Economic Dynamics in Diversified Italian Farms. Bio-Based Appl. Econ. 2013, 2, 257-275.

7. Prayukvong, W.; Huttasin, N.; Foster, M.J. Buddhist Economics Meets Agritourism on the Thai Farm. Int. J. Cult. Tour. Hosp. Res. 2015, 9, 183-199. [CrossRef]

8. European Commission. Agenda 2000. For a Stronger and Wider Union; European Commission: Bruxelles, Belgium, 1997.

9. Haghiri, M.; Okech, R.N. The Role of the Agritourism Management in Developing the Economy of Rural Regions. Tour. Manag. Stud. 2011, 1, 99-105.

10. Mastronardi, L.; Giaccio, V.; Giannelli, A.; Scardera, A. Is Agritourism Eco-Friendly? A Comparison between Agritourisms and Other Farms in Italy Using Farm Accountancy Data Network Dataset. Springerplus 2015, 4, 590-602. [CrossRef] [PubMed]

11. Flanigan, S.; Blackstock, K.; Hunter, C. Generating Public and Private Benefits through Understanding What Drives Different Types of Agritourism. J. Rural Stud. 2015, 41, 129-141. [CrossRef]

12. Saxena, G.; Clark, G.; Oliver, T.; Ilbery, B. Conceptualizing Integrated Rural Tourism. Tour. Geogr. 2007, 9, 347-370. [CrossRef]

13. Forleo, M.B.; Giannelli, A.; Giaccio, V.; Palmieri, N.; Mastronardi, L. Geosites and Parks for the Sustainable Development of Inner Areas: The Matese Mountain (Italy). Geoj. Tour. Geosites 2017, 20, 231-242.

14. Garrod, B.; Wornell, R.; Youell, R. Re-Conceptualising Rural Resources as Countryside Capital: The Case of Rural Tourism. J. Rural Stud. 2006, 22, 117-128. [CrossRef]

15. Koutsouris, A.; Gidarakou, I.; Grava, F.; Michailidis, A. The Phantom of (Agri)Tourism and Agriculture Symbiosis? A Greek Case Study. Tour. Manag. Perspect. 2014, 12, 94-103. [CrossRef]

16. Tew, C.; Barbieri, C. The Perceived Benefits of Agritourism: The Provider's Perspective. Tour. Manag. 2012, 33, 215-224. [CrossRef]

17. Mastronardi, L.; Giaccio, V. Le Performance Delle Aziende Agrarie Con e Senza Agriturismo: Un Confronto Con i Dati RICA. Agriregioneuropa 2011, 26, 83-89.

18. Negri, V. Agro-Biodiversity Conservation in Europe: Ethical Issues. J. Agric. Environ. Ethics 2005, 18, 3-25. [CrossRef]

19. Franch, M. Marketing Delle Destinazioni Turistiche: Metodi, Approcci e Strumenti; Franch, M., Ed.; Franco Angeli: Milano, Italy, 2010.

20. Daugstad, K. Negotiating Landscape in Rural Tourism. Ann. Tour. Res. 2008, 35, 402-426. [CrossRef]

21. Soliva, R.; Rønningen, K.; Bella, I.; Bezak, P.; Cooper, T.; Flø, B.E.; Marty, P.; Potter, C. Envisioning Upland Futures: Stakeholder Responses to Scenarios for Europe's Mountain Landscapes. J. Rural Stud. 2008, 24, 56-71. [CrossRef]

22. Walford, N. Patterns of Development in Tourist Accommodation Enterprises on Farms in England and Wales. Appl. Geogr. 2001, 21, 331-345. [CrossRef]

23. Esposti, R. Agriturismo Al Bivio? Agriregioneuropa 2006, 2, 28-30.

24. Sidali, K.L. A Sideways Look at Farm Tourism in Germany and in Italy. In Food, Agriculture and Tourism. Linking Local Gastronomy and Rural Tourism: Interdisciplinary Perspectives; Sidali, K.L., Spiller, A., Schulze, B., Eds.; Springer Science and Business Media: Berlin, Germany, 2011; pp. 2-24.

25. Giaccio, V.; Giannelli, A.; Mastronardi, L. Explaining Determinants of Agri-Tourism Income: Evidence from Italy. Tour. Rev. 2018, 73, 216-229. [CrossRef] 
26. Boháčková, I.; Hrabánková, M. Influence of Subsidies on Height and Structures of Farmers' Incomes in EU Member States. AGRIS On-Line Pap. Econ. Inform. 2011, 3, $29-43$.

27. Henke, R.; Salvioni, C.; Severini, S.; Tantari, A. Analisi Della Letteratura Ed Evidenze Sui Redditi Agricoli. In I Redditi in Agricoltura: Processi di Diversificazione e Politiche di Sostegno; Henke, R., Salvioni, C., Eds.; INEA: Roma, Italy, 2013; pp. 21-40.

28. Reardon, T.; Berdegué, J.; Barrett, C.B.; Stamoulis, K.; Haggblade, S.; Hazell, P. Household Income Diversification into Rural Nonfarm Activities. In Transforming the Rural Nonfarm Economy; Johns Hopkins University Press: Baltimore, MD, USA, 2006; Chapter 8; p. 34.

29. Fisher, D.G. The Potential for Rural Heritage Tourism in the Clarence Valley of Northern New South Wales. Aust. Geogr. 2006, 37, 411-424. [CrossRef]

30. De Filippis, F.; Fugaro, A. La Politica Di Sviluppo Rurale Tra Presente e Futuro; De Filippis, F., Fugaro, A., Eds.; Tellus: Roma, Italy, 2004.

31. Esposti, R. Knowledge, Technology and Innovations for a Bio-Based Economy: Lessons from the Past, Challenges for the Future. Bio-Based Appl. Econ. 2012, 1, 231-264.

32. Brown, D.M.; Reeder, R.J. Farm-Based Recreation a Statistical Profile; United States Department of Agriculture: Washington, DC, USA, 2007.

33. Kachniewska, M.A. Tourism Development as a Determinant of Quality of Life in Rural Areas. Worldw. Hosp. Tour. Themes 2015, 7, 500-515. [CrossRef]

34. Sotte, F.; Finocchio, R. Guida Alla Diversificazione in Agricoltura; Coldiretti Marche: Ancona, Italy, $2006 ;$ p. 82.

35. Schilling, B.J.; Sullivan, K.P.; Komar, S.J. Examining the Economic Benefits of Agritourism: The Case of New Jersey Department of Agricultural and Resource Management Agents, Rutgers Cooperative Extension of Sussex County. J. Agric. Food Syst. Community Dev. 2012, 3, 199-214. [CrossRef]

36. Vogt, L. The Economic Side of Agritourism: Business Performance and Competitive Factors. Econ. Agro-Aliment. 2013, 15, 77-102.

37. Sgroi, F.; Donia, E.; Mineo, A.M. Agritourism and Local Development: A Methodology for Assessing the Role of Public Contributions in the Creation of Competitive Advantage. Land Use Policy 2018, 77, 676-682. [CrossRef]

38. Giarè, F.; Henke, R.; Vanni, F. I Processi Di Diversificazione Nelle Aziende Peri-Urbane: Casi Di Successo a Confronto. Agriregionieuropa 2016, 12, 22-26.

39. Galluzzo, N. Role of Subsidies Allocated by the Second Pillar of the Common Agricultural Policy and Diversification in Romanian Farms through Agritourism. Roman. Rev. Reg. Stud. 2016, 12, 65-78.

40. Barbieri, C. Assessing the Sustainability of Agritourism in the US: A Comparison between Agritourism and Other Farm Entrepreneurial Ventures. J. Sustain. Tour. 2013, 21, 252-270. [CrossRef]

41. Mastronardi, L.; Giaccio, V.; Giannelli, A.; Scardera, A. Agriturismo e Sostenibilità Ambientale. Primi Risultati Di Un'analisi Aziendale. Agriregionieuropa 2015, 40, 55-58.

42. Mastronardi, L.; Cipollina, M. Una Riflessione Sulla Sostenibilità Del Turismo Rurale Alla Luce Dei Legami Tra Agricoltura, Turismo e Ambiente. Riv. Econ. Agrar. 2009, 1-2, 195-224.

43. Colton, J.W.; Bissix, G. Developing Agritourism in Nova Scotia: Issues and Challenges. J. Sustain. Agric. 2005, 27, 91-112. [CrossRef]

44. Naidoo, P.; Sharpley, R. Local Perceptions of the Relative Contributions of Enclave Tourism and Agritourism to Community Well-Being: The Case of Mauritius. J. Destin. Mark. Manag. 2016, 5, 16-25. [CrossRef]

45. Capriello, A.; Rotherham, I.D. Farm Attractions, Networks, and Destination Development: A Case Study of Sussex, England. Tour. Rev. 2008, 63, 59-71. [CrossRef]

46. El Benni, N.; Finger, R.; Mann, S.; Lehmann, B. The Distributional Effects of Agricultural Policy Reforms in Switzerland. Agric. Econ. 2012, 58, 510-519. [CrossRef]

47. Milone, P.; Ventura, F. Is Multifunctionality the Road to Empowering Farmers? In Research in Rural Sociology and Development; Milone, P., Ventura, F., Ye, J., Eds.; Emerald Group Publishing Limited: Bingley, UK, 2015; Volume 22, pp. 59-88.

48. Bagi, F.S.; Reeder, R.J. Factors Affecting Farmer Participation in Agritourism. Agric. Resour. Econ. Rev. 2012, 41, 189-199. [CrossRef]

49. Lupi, C.; Giaccio, V.; Mastronardi, L.; Giannelli, A.; Scardera, A. Exploring the Features of Agritourism and Its Contribution to Rural Development in Italy. Land Use Policy 2017, 64, 383-390. [CrossRef] 
50. Roberts, L. Farm Tourism. Its Contribution to the Economic Sustainability of Europe's Countryside. In Sustainable Tourism: A Global Perspective; Harris, R., Griffin, T., Williams, P., Eds.; Butterworth-Heinemann: Oxford, UK, 2002; pp. 195-208.

51. Marotta, G.; Nazzaro, C. Value Portfolio in the Multifunctional Farm: New Theoretical-Methodological Approaches. Riv. Econ. Agrar. 2012, 2, 7-36.

52. Marotta, G.; Nazzaro, C. Verso Un Nuovo Paradigma per La Creazione Di Valore Nell'impresa Agricola Multifunzionale. Il Caso Della Filiera Zootecnica. Econ. Agro-Aliment. 2011, 1-2, 1-36.

(c) 2018 by the authors. Licensee MDPI, Basel, Switzerland. This article is an open access article distributed under the terms and conditions of the Creative Commons Attribution (CC BY) license (http:/ / creativecommons.org/licenses/by/4.0/). 